University of South Florida

DIGITAL COMMONS

Digital Commons @ University of

@ UNIVERSITY OF SOUTH FLORIDA

South Florida

6-11-2003

\title{
Millennial- to Century-Scale Variability in Gulf of Mexico Holocene Climate Records
}

\author{
R. Z. Poore \\ U.S. Geological Survey \\ H. J. Dowsett \\ U.S. Geological Survey \\ S. Verardo \\ U.S. Geological Survey \\ Terrence M. Quinn \\ University of South Florida, quinn@marine.usf.edu
}

Follow this and additional works at: https://digitalcommons.usf.edu/msc_facpub

Part of the Marine Biology Commons

\section{Scholar Commons Citation}

Poore, R. Z.; Dowsett, H. J.; Verardo, S.; and Quinn, Terrence M., "Millennial- to Century-Scale Variability in Gulf of Mexico Holocene Climate Records" (2003). Marine Science Faculty Publications. 112.

https://digitalcommons.usf.edu/msc_facpub/112

This Article is brought to you for free and open access by the College of Marine Science at Digital Commons @ University of South Florida. It has been accepted for inclusion in Marine Science Faculty Publications by an authorized administrator of Digital Commons @ University of South Florida. For more information, please contact digitalcommons@usf.edu. 


\title{
Millennial- to century-scale variability in Gulf of Mexico Holocene climate records
}

\author{
R. Z. Poore, H. J. Dowsett, and S. Verardo \\ U.S. Geological Survey, Reston, Virginia, USA
}

T. M. Quinn

College of Marine Science, University of South Florida, St. Petersburg, Florida, USA

Received 25 November 2002; revised 26 February 2003; accepted 7 April 2003; published 11 June 2003.

[1] Proxy records from two piston cores in the Gulf of Mexico (GOM) provide a detailed (50-100 year resolution) record of climate variability over the last 14,000 years. Long-term (millennial-scale) trends and changes are related to the transition from glacial to interglacial conditions and movement of the average position of the Intertropical Convergence Zone (ITCZ) related to orbital forcing. The $\delta^{18} \mathrm{O}$ of the surface-dwelling planktic foraminifer Globigerinoides ruber show negative excursions between 14 and 10.2 ka (radiocarbon years) that reflect influx of meltwater into the western GOM during melting of the Laurentide Ice Sheet. The relative abundance of the planktic foraminifer Globigerinoides sacculifer is related to transport of Caribbean water into the GOM. Maximum transport of Caribbean surface waters and moisture into the GOM associated with a northward migration of the average position of the ITCZ occurs between about 6.5 and $4.5 \mathrm{ka}$. In addition, abundance variations of $G$. sacculifer show century-scale variability throughout most of the Holocene. The GOM record is consistent with records from other areas, suggesting that century-scale variability is a pervasive feature of Holocene climate. The frequency of several cycles in the climate records is similar to cycles identified in proxy records of solar variability, indicating that at least some of the century-scale climate variability during the Holocene is due to external (solar) forcing. $\quad$ INDEX TERMS: 4267 Oceanography: General: Paleoceanography; 9604 Information Related to Geologic Time: Cenozoic; 3030 Marine Geology and Geophysics: Micropaleontology; KEYWORDS: Holocene, Gulf of Mexico, millennial- to century-scale climate variability, solar forcing

Citation: Poore, R. Z., H. J. Dowsett, S. Verardo, and T. M. Quinn, Millennial- to century-scale variability in Gulf of Mexico Holocene climate records, Paleoceanography, 18(2), 1048, doi:10.1029/2002PA000868, 2003.

\section{Introduction}

[2] Proxy climate records for the current interglacial interval, or Holocene, contain clear evidence for significant variability and abrupt change. For example, studies based on tree rings, lake sediments, and geomorphic features indicate that several multidecadal- to century-long droughts affected the central United States during the last 2,000 years [Woodhouse and Overpeck, 1998]. Multidecadal droughts during the 13th and 16th centuries were more severe and widespread than the "dust bowl" event of the 1930s and at least four severe, century-scale "megadroughts" affected the Great Plains and western United States between AD 1 and AD 1200 (summary of Woodhouse and Overpeck [1998]). A detailed multiproxy record from Pyramid Lake, Nevada [Benson et al., 2002] indicates multidecadal- to century-long droughts affected northern California and Nevada every 80 to 230 years during the last 2740 years (calendar years). Ice core records from Greenland contain evidence for a major global cold event at about 7,500 radiocarbon years ago (8,200 cal years ago) [Alley et al., 1997]. Millennial-scale climate variability during the Holo-

Copyright 2003 by the American Geophysical Union. 0883-8305/03/2002PA000868 cene is recorded in $\mathrm{CaCO}_{3}$ records from North Atlantic drift deposits [Keigwin and Jones, 1989]. Continuous multiproxy records from marine cores in the subpolar and subtropical North Atlantic [Bond et al., 1997, 1999; DeMenocal et al., 2000] indicate that the current interglacial was punctuated by a series of quasiperiodic cold events that occurred about every 1500 years. The most recent cold event, the Little Ice Age (LIA), was preceded by a period of warmer climate, the Medieval Warm Period (MWP). The LIA and MWP are prominent in $\mathrm{CaCO}_{3}$ and isotope records from high deposition rate Bermuda Rise cores [Keigwin, 1996]. Quasiperiodic cycles of cold and warm intervals during the Holocene have been documented in the advance and recession records of mountain glaciers [Denton and Karlén, 1973]. The North Atlantic marine and mountain glacier data suggest that climate throughout the Holocene has oscillated between warm and cold end-members with the MWP and LIA representing the most recent examples of the cycle extremes.

[3] Although proxy records provide clear evidence that the climate of the Holocene is highly variable, the details of the variability and regional patterns of change are poorly known. In addition the causes of high-frequency variability are uncertain. Some workers argue that high-frequency variability (millennial- to submillennial-scale) is due to 


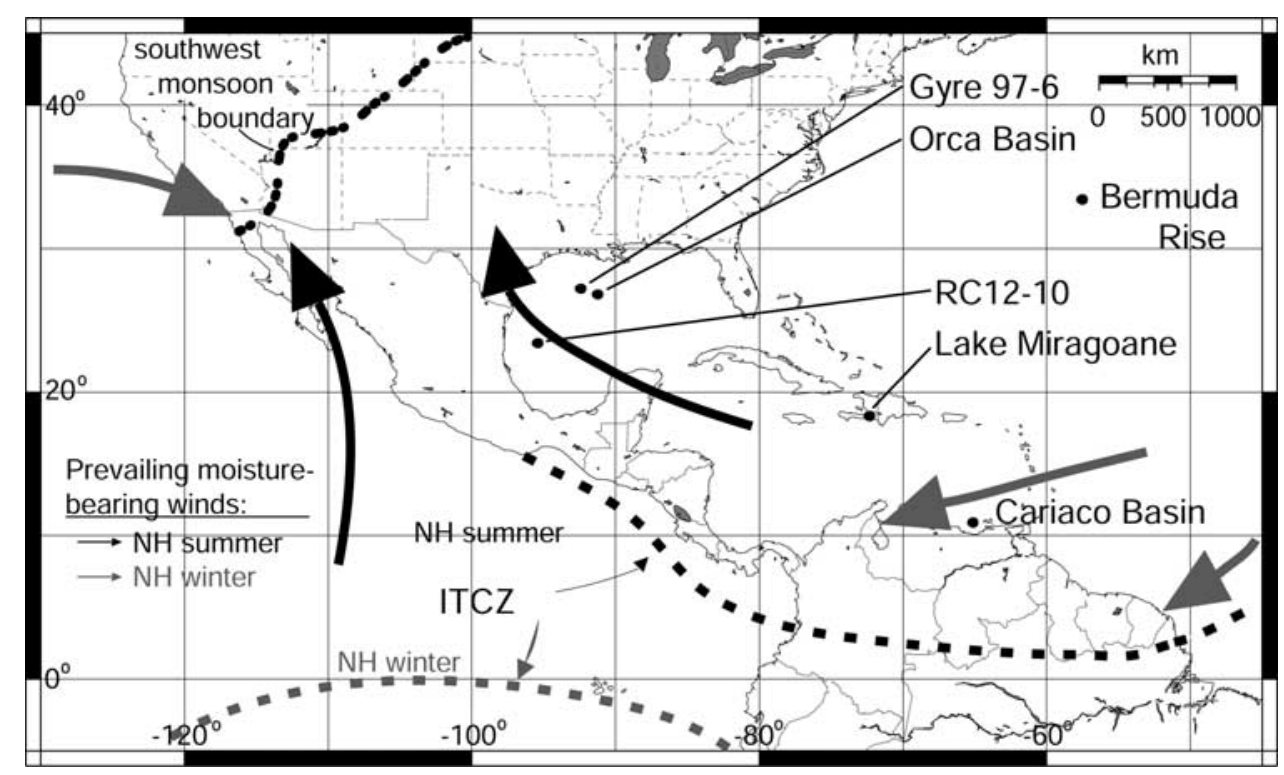

Figure 1. Map showing location of cores and climate records discussed in text. Generalized path of prevailing moisture bearing winds and position of the Intertropical Convergence Zone (ITCZ) for Northern Hemisphere winter and summer are shown by bold arrows and dashed lines. Bold dotted line shows approximate northern limit of monsoon boundary where more than $50 \%$ of annual precipitation occurs during the warm season. Adapted from Mayle et al. [2000], Metcalfe et al. [2000], and Petersen [1994].

external (solar) forcing [e.g., Denton and Karlén, 1973; Bond et al., 2001] and others argue that high-frequency variability is caused by internal dynamics of the global climate system [e.g., Cane and Clement, 1999]. Better characterization of Holocene climate variability and the effects of the variability on specific regions are needed to establish the likely forcing and help discriminate between natural climate variability and any human-related climate changes.

[4] In this report we present a record of climate variability from the Gulf of Mexico (GOM) that extends back 14 ka radiocarbon years (Figure 1). The GOM is a semi-enclosed basin at the northwestern edge of the tropical Atlantic Ocean. Information on the history of climate variability in the GOM region is of interest because the GOM is the source of moisture for a large area of North America, Greenland and the North Atlantic region [Peixóto and Oort, 1983]. Sea-surface temperatures (SST) in the GOM determine the amount of water vapor transported out of the GOM and influence North Atlantic storm tracks [Oglesby et al., 1989]. In addition, the high sediment accumulation rates in the GOM allow development of records with submillennial to decadal resolution.

[5] The primary surface-ocean current in the GOM is the Loop Current that brings warm waters from the Caribbean Sea through the Yucatan Strait into the GOM. The Loop Current exits the GOM into the North Atlantic Ocean through the Florida Straits. Surface-water and wind circulation in the Caribbean GOM region show large annual changes linked to seasonal migration of the Intertropical Convergence Zone (ITCZ) (Figure 1). During Northern Hemisphere winter, the ITCZ lies near the equator and easterly winds from the Atlantic blow onto South America, bringing rains to the Amazon Basin. Prevailing westerly surface winds in the GOM region bring moisture into the west coast of North America from the Pacific. Precipitation in the southwest United States and eastern Mexico is low [Tang and Reiter, 1984]. The Loop Current generally does not penetrate into the western or northern GOM. Warm, tropical waters from the Caribbean are usually restricted to the southeastern GOM reflecting the flow of the Loop Current from the Yucatan Strait to the Florida Strait. However, the penetration of the Loop Current into the northern GOM varies from year to year and anticyclonic eddies which break off of the Loop Current at irregular intervals can bring warm waters to the northern and central GOM during some winters [Müller-Karger et al., 1991].

[6] During Northern Hemisphere summer (Figure 1), the ITCZ moves north of the equator owing to warming of the Northern Hemisphere. The northward movement of the ITCZ results in southeasterly surface winds across the Caribbean Sea and GOM and northerly winds across the Gulf of California bringing summer moisture to Mexico and the southwestern United States (the American monsoon). Surface flow through the Yucatan Strait is increased and the Loop Current penetrates deep into the GOM [Sheinbaum et al., 2002; Müller-Karger et al., 1991]. SSTs are near $29^{\circ} \mathrm{C}$ throughout the GOM.

[7] Most previous studies of the marine climate history of the GOM concentrated on major changes associated with glacial-interglacial transitions (i.e., orbital-scale variations). For example the relative abundance of the planktic foraminifer Globorotalia menardii (s.l.) was used to establish a series of zones $(\mathrm{Q}-\mathrm{Z})$ in sediments from the tropical 
Atlantic and Caribbean that represented alternating warm and cold climate intervals of the late Pleistocene [Ericson and Wollin, 1968]. Kennett and Huddlestun [1972] used relative abundance variations of individual species of planktic foraminifers in a series of cores from the western GOM to establish quantitative changes in foraminifer assemblages associated with Pleistocene glacial-interglacial cycles and identified species that were warm and cool water indicators in the GOM. Kennett and Huddlestun [1972] established subdivisions of the $\mathrm{Q}-\mathrm{Z}$ zonation of Ericson and Wollin [1968] on the basis of frequency variations in the planktic foraminifer assemblages. Zone Z ( Holocene) was divided into two subzones on the basis of the last occurrence of Globorotalia crassaformis. However, Zone Z was not sampled or studied in detail. Malmgren and Kennett [1976] did a principal component analysis of the foraminiferal assemblage data from Kennett and Huddlestun [1972] and found that the first principle component contrasted warm and cool species. Brunner [1982] used the transfer function technique of Imbrie and Kipp [1971] to estimate SSTs and salinities extending back through the last interglacial in several cores from the GOM. The quantitative estimates of SST by Brunner [1982] differ in detail with previous studies but show the same general pattern. Sample resolution was designed to establish the glacial-interglacial signal. Only a few Holocene temperature estimates are available, although some records show evidence for a mid-Holocene winter temperature maximum [Brunner, 1982, Figure 8].

[8] More detailed information on the character of the Holocene record in the GOM is available from cores from the Orca Basin on the Louisiana Slope south of the Mississippi River Delta (Figure 1). As part of studies into the impact of meltwater influx into the GOM during the last deglaciation, Kennett et al. [1985] and Flower and Kennett [1990, 1995] determined the relative abundance of planktic foraminifers and $\delta^{18} \mathrm{O}$ of Globigerinoides ruber (white variety) at a sampling interval of about 250 to 300 years in cores EN 32-PC6 and EN 32-PC4. The foraminiferal assemblages show clear differences between older and younger parts of the Holocene (Zones Z2 and Z1). The warmest SST, as reflected by high relative abundances of Pulleniatina obliquiloculata and G. menardii [Flower and Kennett, 1995], occurred at about 5 ka. Brown et al. [1999] used faunal, isotopic, and grain-size variations in core EN 32-PC2 from the Orca Basin to identify seven major flood events that occurred every 500 to 1,200 years over the last 5,000 years. Sample resolution varies from a century to several decades. However, data from EN 32-PC2 are difficult to interpret because they are noisy and considerable variation is seen in the effects of individual flood events on the faunal, isotope, and grain-size data.

\section{Materials and Methods}

[9] Our study is based on data from two piston cores, RC 12-10 from the western GOM and Gyre 97-6 PC20 from the Louisiana continental slope in the northern GOM (Figure 1). RC12-10 (lat. $23.00^{\circ} \mathrm{N}$, long. $95.53^{\circ} \mathrm{W}$ ) was raised from $3054 \mathrm{~m}$ water depth in the western GOM in
1968 and stored at Lamont-Doherty Earth Observatory (Figure 1). The core was desiccated and brittle owing to storage at room temperature. Sampled in 2000, most of the core was coherent except the upper $10 \mathrm{~cm}$, which was crumbled, and little material was available for sampling. Calipers, prestorage photographs and depth markers were used to adjust sample depths for shrinkage during storage. The upper part of the core was sampled continuously using a diamond saw in 1 to $2 \mathrm{~cm}$ increments. Gyre 97-6 PC20 (lat. $26.22^{\circ} \mathrm{N}$, long. $91.92^{\circ} \mathrm{W}$ ) was raised from $2040 \mathrm{~m}$ water depth on the Louisiana Continental slope and stored at Woods Hole Oceanographic Institute. Gyre 97-6 PC 20 (Figure 1) was sampled at $1 \mathrm{~cm}$ intervals.

[10] Sediment samples were disaggregated in a beaker of warm water on an oscillating shaker table. About $10 \mathrm{ml}$ of dilute Calgon solution were added during disaggregation to help disperse clay-size material. After disaggregation, samples were wet sieved at $63 \mu \mathrm{m}$ and the $>63 \mu \mathrm{m}$ residue was oven dried at approximately $50^{\circ} \mathrm{C}$. Some samples required more than one cycle to obtain clean specimens. If required to eliminate organic material, approximately $5 \mathrm{ml}$ of $10 \% \mathrm{H}_{2} \mathrm{O}_{2}$ was added to the water and Calgon solution. The clean $>63 \mu \mathrm{m}$ residues were dry sieved and separated into $63 \mu \mathrm{m}-150 \mu \mathrm{m}$ and $>150 \mu \mathrm{m}$ size fractions. A CARPCO microsplitter was used to obtain a split of approximately 300 individuals from the $>150 \mu \mathrm{m}$ fraction for a census of the planktic foraminifer assemblage. Foraminifers in the census split were sorted by species, and glued onto a standard 60 square micropaleontology slide. Planktic foraminifers were identified following the taxonomy of Parker [1962], as modified by Poore [1979]. Benthic foraminifers were grouped in a single category. Abundances of planktic foraminifers are reported as percent of the total planktic foraminiferal assemblage.

[11] SST estimates for RC 12-10 were generated using a factor analytical transfer function (GOM2) developed for the GOM [Dowsett et al., 2003a, 2003b]. The transfer function is calibrated by 22 AMS $14 \mathrm{C}$ dated core top samples from the GOM [see Dowsett et al., 2003a, 2003b]. We used the INTCAL 98 radiocarbon age calibration of Stuiver et al. [1998] to convert the ${ }^{14} \mathrm{C}$ ages of the core top samples to calendar years before present. Fourteen of the core top samples yielded ages of 0 years. Five of the core top samples yielded ages between 150 and 650 years. Three of the core top samples yielded ages between 1000 and 1500 years. The standard error of estimate is $1.76^{\circ} \mathrm{C}$ for winter (February) and $0.06^{\circ} \mathrm{C}$ for summer (August) SST. However, the range of August SST in the calibration data set is very small which makes the GOM2 estimates unreliable for down-core summer SST reconstruction.

[12] Stable isotope analyses for RC 12-10 were done on 12-15 individuals of Globigerinoides ruber (white variety) from the $212 \mu \mathrm{m}$ to $250 \mu \mathrm{m}$ size fraction. When possible only individuals with apertures free of matrix were selected for analyses. Occasionally it was necessary to clean specimens in an ultrasonic bath to disperse matrix from apertures. Samples were reacted with anhydrous phosphoric acid at $70^{\circ} \mathrm{C}$ in individual reaction vessels of a Kiel III carbonateextraction system coupled to a ThermoFinnigan DeltaPlus XL mass spectrometer at the University of South Florida. Precision $( \pm 2 \sigma)$ was monitored by daily analyses of pow- 
Table 1. $\mathrm{AMS}^{14} \mathrm{C}$ Dates From RC 12-10 and Gyre 97-6 PC20

\begin{tabular}{lrrrr}
\hline Core & $\begin{array}{c}\text { Depth, } \\
\text { cm }\end{array}$ & Age, Years BP & \pm & $\begin{array}{c}\text { Reservoir Corrected } \\
\text { Age }\end{array}$ \\
\hline RC 12-10 & & & & \\
& 1.0 & 940 & 35 & 540 \\
& 17.0 & 1390 & 30 & 990 \\
& 50.5 & 3185 & 60 & 2785 \\
& 100.5 & 5325 & 60 & 4925 \\
& 135.0 & 6985 & 50 & 6585 \\
& 173.0 & 9350 & 40 & 8950 \\
& 211.0 & 12085 & 45 & 11685 \\
Gyre 97-6 PC20 & 255.0 & 15710 & 45 & 15310 \\
& & & & \\
& 11.5 & 830 & 30 & 430 \\
& 40.0 & 2340 & 40 & 1940 \\
& 77.5 & 3540 & 30 & 3140 \\
& 100.0 & 4900 & 40 & 4500 \\
& 140.0 & 6870 & 40 & 6470 \\
& 160.0 & 8300 & 40 & 7900 \\
& 185.5 & 10050 & 35 & 9650 \\
\hline
\end{tabular}

dered calcite standard (NBS-19) and was better than $0.08 \%$ o for both oxygen and carbon. Values are reported in standard $\delta$ notation relative to Vienna Peedee belemnite (V-PDB). Faunal and isotope data are in the work of Dowsett et al. [2003a, 2003b].

[13] Chronologies for RC 12-10 and Gyre 97-6 PC 20 are based on AMS ${ }^{14} \mathrm{C}$ dates on mixed planktic foraminifers. Samples of 10-20 mg were converted to graphite targets at the U.S. Geological Survey, Reston, VA. AMS ${ }^{14} \mathrm{C}$ ages were determined at the Center for Accelerator Mass Spectrometry, Lawrence Livermore National Laboratory in Livermore, $\mathrm{Ca}$. The quoted ages are in radiocarbon years (BP) using the Libby half-life of 5568 years (Table 1). Age models were constructed from radiocarbon dates in each core using a polynomial fit and a uniform reservoir correction of 400 years (Figure 2). The independent age models show a nearly uniform accumulation rate of $\sim 20 \mathrm{~cm} / 1000$ years for the intervals studied in RC 12-10 and Gyre 97-6 PC 20. The projected ${ }^{14} \mathrm{C}$ ages for the tops of RC 12-10 and Gyre 97-6 PC 20 are $\sim 600$ and $\sim 230$ years, respectively. Sample spacing of the RC 12-10 record varies between 50 and 100 years. Sample spacing in Gyre 97-6 PC 20 is about 50 years. We have faunal data at similar resolution from both cores for the last $7.2 \mathrm{ka}$. The ages reported in this study are in radiocarbon years before the present. Exceptions are noted in the text.

\section{Planktic Foraminifer Distribution and SST Estimates}

[14] Foraminifers are abundant and generally moderately well to well preserved in samples from RC 12-10. Increased fragmentation of planktic foraminifers above $45 \mathrm{~cm}$ $(\sim 2.5 \mathrm{ka})$ in the core shows evidence of increased dissolution. The stratigraphic distribution of the relative abundance of important species and species groups in our samples from RC 12-10 are shown in Figure 3. Globigerinoides ruber (pink and white varieties) is abundant in all samples and usually makes up between 40 and $60 \%$ of the total assemblage. The most obvious feature in the G. ruber record is a minimum centered at about $1.2 \mathrm{ka}$ within the interval of increased dissolution. The overall variability of $G$. ruber is lowest between about 7.5 ka and 9.0 ka. Other taxa show distinctive stratigraphic trends (Figure 3). The G. menardii group, G. truncatulinoides and P. obliquiloculata increase in abundance upsection. Globigerina falconensis and G. bulloides decrease in abundance upsection. Globorotalia crassaformis essentially disappears from the foraminifer assemblage at about $7 \mathrm{ka}$ but then reappears for a short interval around $3 \mathrm{ka}$. Globigerinoides sacculifer first increases in abundance upsection to a broad maximum at about $5.5 \mathrm{ka}$ and then decreases in abundance toward the top of the section. All taxa show considerable high-frequency variability superimposed on the overall trends.

[15] The overall changes in the planktic foraminifer abundances from RC 12-10 match previously documented changes in the GOM foraminifer assemblages related to the transition from glacial to interglacial conditions. Several studies [e.g., Kennett and Huddlestun, 1972; Flower and Kennett, 1995] show that P. obliquiloculata and the G. menardii group are warm water (interglacial) indicators whereas G. falconensis, G. bulloides and G. crassaformis are cool water indicators. The gradual increase of G. truncatulinoides through the Holocene has been documented in a number of cores from the western GOM [Kennett and Huddlestun, 1972]. The abundance variations of several key foraminifers in RC 12-10 and Gyre 97-6 PC 20 are compared in Figure 4. Inspection of Figure 4 reveals that the overall trends in abundance variations and character of highfrequency variability of taxa in the two cores are very similar

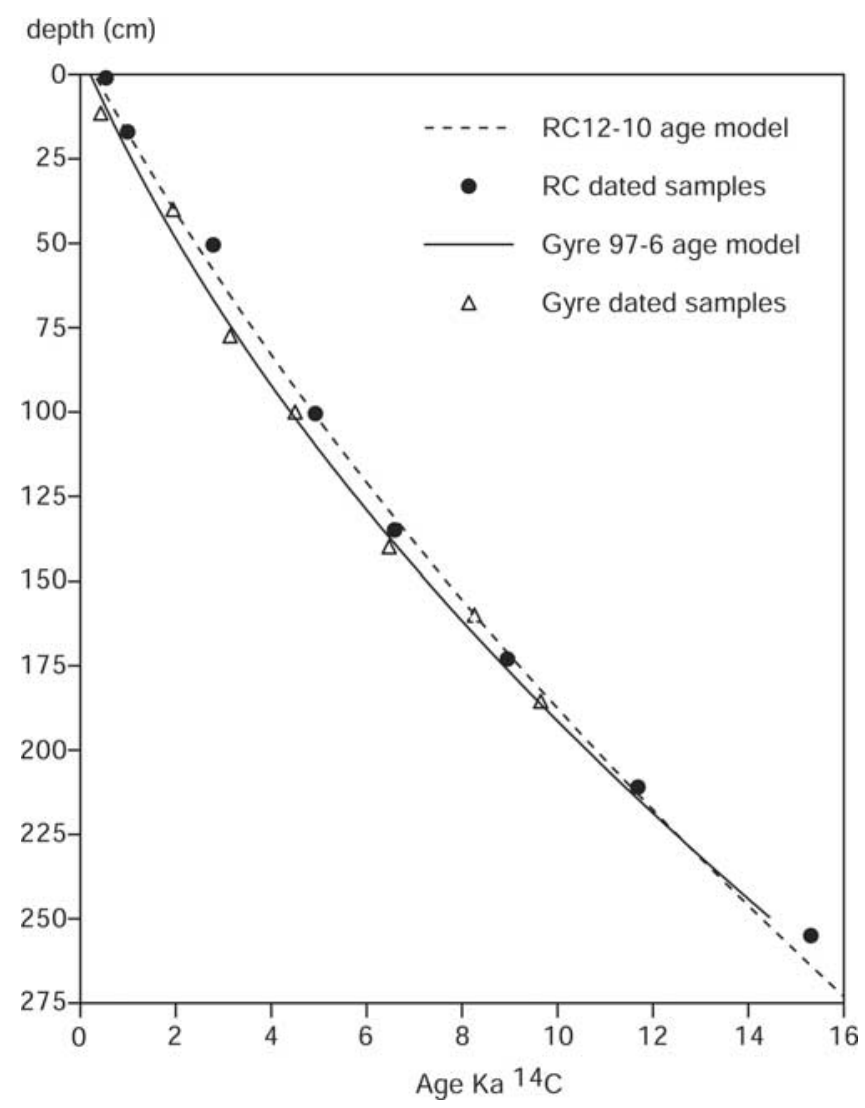

Figure 2. Age model for RC 12-10 and Gyre 97-6, PC 20. 

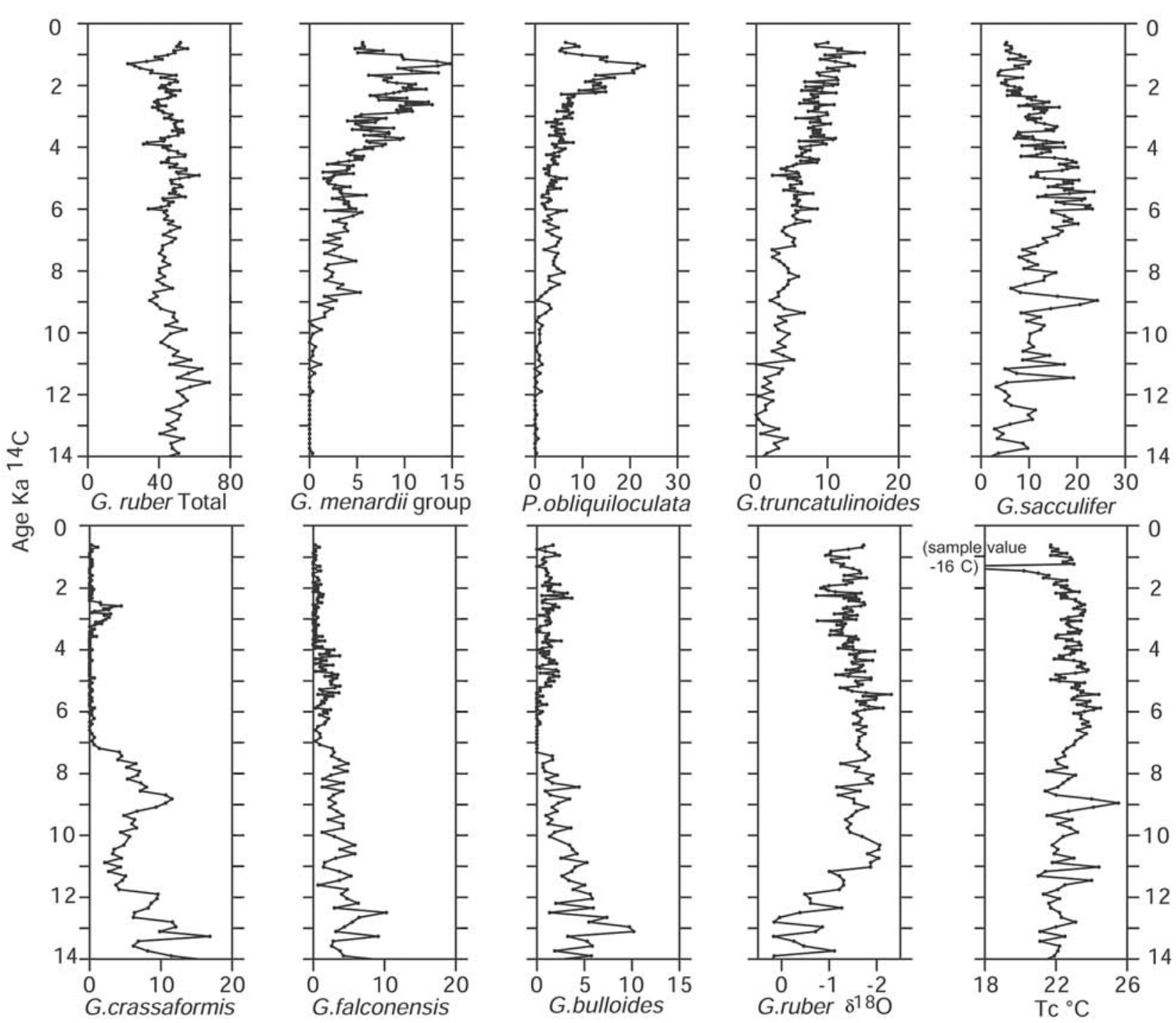

Figure 3. Stratigraphic plots of relative abundance of selected planktic foraminifers, $\delta^{18} \mathrm{O}$ for Globigerinoides ruber (white variety) and winter sea-surface temperature estimates in RC 12-10. Data are from the work of Dowsett et al. [2003b].

even though Gyre 97-6 PC 20 was recovered from the Louisiana slope in the northern Gulf (see Figure 1). Globorotalia crassaformis disappears in both records at about $7 \mathrm{ka}$, which is consistent with previous studies (the Z1/Z2 boundary of Kennett and Huddlestun [1972]. However, G. crassaformis then reappears in both cores at $\sim 3.2 \mathrm{ka}$ for several hundred years. We conclude that the brief reappearance of G. crassaformis in the foraminifer assemblages at about $3.2 \mathrm{ka}$ is a regional-scale environmental event and not an artifact of reworking or variable preservation.

[16] The peak abundance of $P$. obliquiloculata between 1.6 and $1.3 \mathrm{ka}$ in RC 12-10 is not reflected in the Gyre 97-6 PC 20 record. The RC 12-10 P. obliquiloculata abundance maximum occurs in the zone of increased dissolution and P. obliquiloculata is very resistant to dissolution [e.g., Boltovskoy and Toutah, 1992]. Thus the maximum abun- dance of P. obliquiloculata in RC 12-10 could be due, in part, to dissolution. However, the abundance variations of G. truncatulinoides and the G. menardii group, which are also dissolution resistant, do not show an abundance peak associated with the P. obliquiloculata maximum. In contrast to the results of Flower and Kennett [1995] we do not observe a maximum in $P$. obliquiloculata at $5 \mathrm{ka}$.

[17] We obtained winter and summer SST estimates from the total fauna census data. Modern winter SST values (February) in the vicinity of RC $12-10$ are near $22^{\circ} \mathrm{C}$ (Figure 5) and summer (August) SST values are about $29^{\circ} \mathrm{C}$ throughout the GOM (atlas data). The faunal SST estimates suggest relatively small temperature changes occurred at the site of RC 12-10 over much of the last $14 \mathrm{ka}$. Winter SSTs show the most variability (Figure 3). SSTs older than about $9 \mathrm{ka}$ are generally between $21^{\circ} \mathrm{C}$ and 

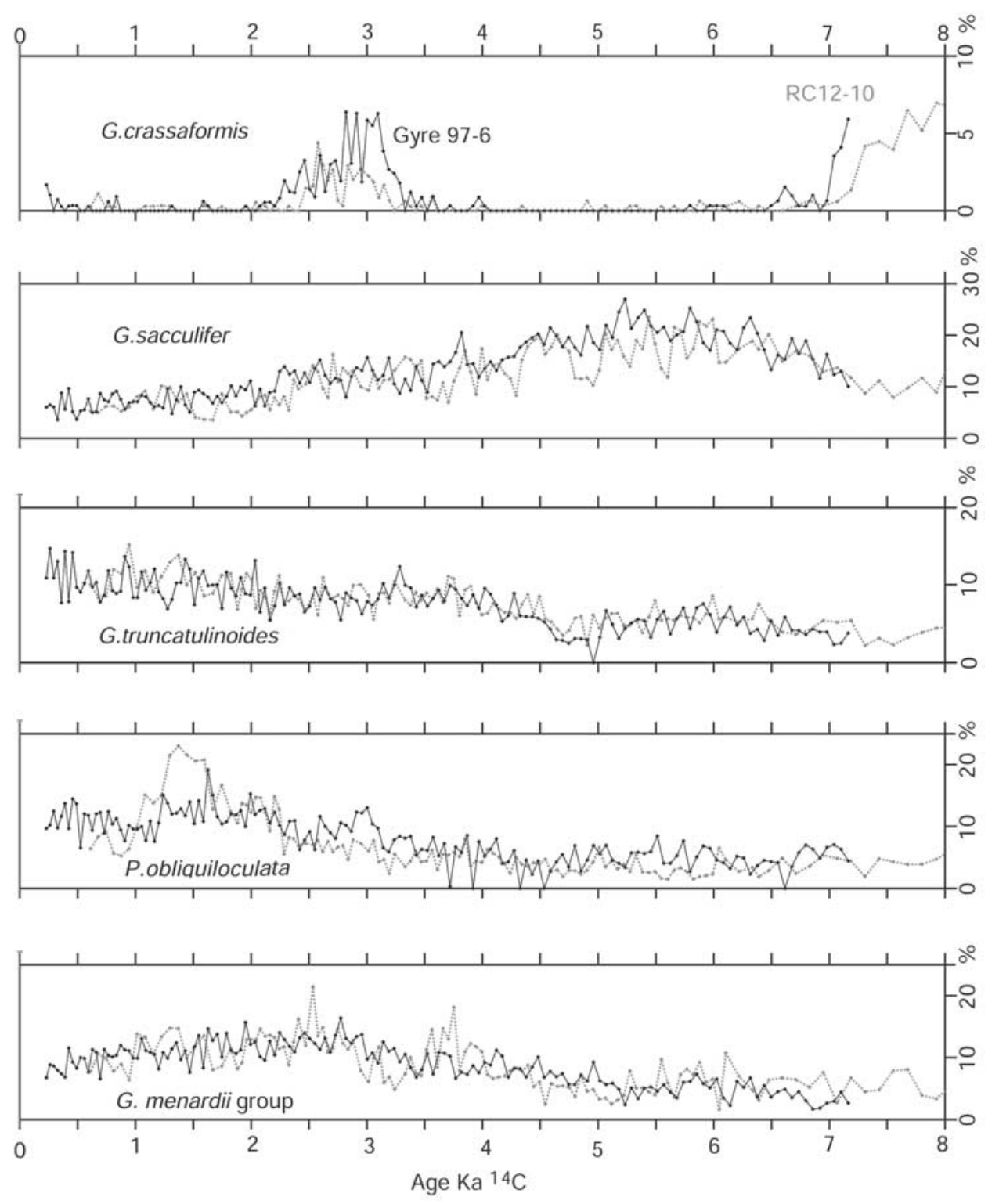

Figure 4. Comparison of relative abundance variations of selected planktic foraminifers in RC 12-10 and Gyre 97-6, PC 20. Chronology is based on independent AMS ${ }^{14} \mathrm{C}$-controlled age models for each core (Figure 2). See color version of this figure at back of this issue.

$23^{\circ} \mathrm{C}$. Very warm values at $9 \mathrm{ka}$ coincide with a marked peak in the abundance of $G$. sacculifer. The general decrease of cool water indicators, G. bulloides and G. falconensis, between $14 \mathrm{ka}$ and $10 \mathrm{ka}$ (Figure 3) suggests increasing SST. However, the SST estimates do not show a clear warming trend between $14 \mathrm{ka}$ and $10 \mathrm{ka}$. We conclude that any trend to increasing temperatures is too small to be reflected in the transfer function SST estimates. In addition the temperature signal in this interval may be complicated by meltwater events. SSTs between 7 and $5 \mathrm{ka}$ suggest warming of winter surface temperatures. SSTs are consistently above $23^{\circ} \mathrm{C}$ and several estimates exceed $24^{\circ} \mathrm{C}$. The indicated warming of $1.5^{\circ} \mathrm{C}$ to $2^{\circ} \mathrm{C}$ is within the standard error of the SST estimates $\left(1.76^{\circ} \mathrm{C}\right)$. However, the consistent occurrence of warmer SST estimates between 7 and $5.2 \mathrm{ka}$ suggests that the indicated warming is reliable. SSTs between 5 and $2 \mathrm{ka}$ are more variable and slightly cooler. Most values are between 22.5 and $23.5^{\circ} \mathrm{C}$. Winter (and summer SST) values around $1.5 \mathrm{ka}$ are anomalously low, likely due to dissolution effects. Most summer SST estimates (not plotted) are near $29^{\circ} \mathrm{C}$. However, summer SSTs are not considered reliable because of the limited range of August SSTs in the core-top calibration set.

\section{Oxygen Isotope Data and Trends}

[18] $\delta^{18} \mathrm{O}$ from G. ruber (white variety) in the older part of the RC 12-10 record show a series of negative excursions 


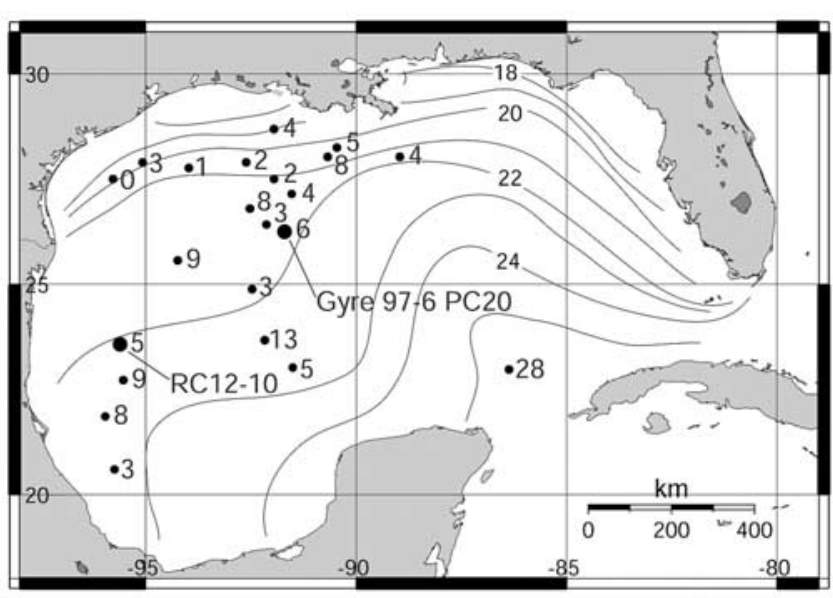

Figure 5. Map showing relative abundance of the planktic foraminifer Globigerinoides sacculifer in core top assemblages that are judged to be modern or near modern in age [Dowsett et al., 2003a, 2003b]. Small filled circles represent sample locations, and numbers next to the filled circles are the percent $G$. sacculifer in the planktic foraminifer assemblage $(>150 \mu \mathrm{m})$. Contours are winter sea-surface temperatures in ${ }^{\circ} \mathrm{C}$ from Brunner [1982].

superimposed on a general upsection trend to more negative $\delta^{18} \mathrm{O}$ that culminates in an interval of minimum $\delta^{18} \mathrm{O}$ near $-2.0 \%$ centered at about $10.5 \mathrm{ka}$ (Figure 3 ). The total range of variation between the base of the record and the minima centered at $10.5 \mathrm{ka}$ exceeds $2 \%$. $\delta^{18} \mathrm{O}$ then increase slightly starting at $\sim 10.2 \mathrm{ka}$ to about $-1.4 \%$ at $\sim 9.7 \mathrm{ka}$. Most $\delta^{18} \mathrm{O}$ between 9.5 and $4 \mathrm{ka}$ fluctuate around a mean value of $\sim-1.6 \%$. Minimum $\delta^{18} \mathrm{O}$ fall between $-2.0 \%$ and $-2.2 \%$. At $4 \mathrm{ka} \delta^{18} \mathrm{O}$ becomes more positive. $\delta^{18} \mathrm{O}$ variability is still high but mean $\delta^{18} \mathrm{O}$ is $\sim-1.3 \%$ and minima fall between $-1.5 \%$ and $-1.7 \%$.

[19] During the last deglaciation, melting of the Laurentide Ice Sheet resulted in large amounts of freshwater discharge down the Mississippi River into the GOM. Because meltwater is enriched in ${ }^{16} \mathrm{O}$ compared to seawater, the influx of meltwater into the GOM during the deglaciation is reflected in $\delta^{18} \mathrm{O}$ from surface-dwelling planktic foraminifers like G. ruber [e.g., Kennett and Shackleton, 1975; Leventer et al., 1982]. Excursions to more negative foraminifer $\delta^{18} \mathrm{O}$ values represent increased meltwater influx. The $\delta^{18} \mathrm{O}$ record of $G$. ruber in RC $12-10$ between 14 and $7.5 \mathrm{ka}$ is consistent with previous studies and shows that the western GOM was influenced by glacial meltwater influx during the last deglaciation. Excursions to negative $\delta^{18} \mathrm{O}$ between 14 and $11 \mathrm{ka}$ and the sustained interval of very negative $\delta^{18} \mathrm{O}$ centered at about $10.5 \mathrm{ka}$ represent the influence of meltwater discharged into the GOM during the initial melting of the Laurentide Ice Sheet, or meltwater pulse 1 [Kennett et al., 1985; Broecker et al., 1989; Flower and Kennett, 1990, 1995; Flower et al., 2002]. Previous studies of cores from the Orca Basin in the GOM and cores from the eastern North Atlantic indicate that meltwater pulse 1 included at least three separate meltwater events centered at about $13.5 \mathrm{ka}, 12 \mathrm{ka}$, and $11 \mathrm{ka}$ (?) (summarized by Keigwin et al. [1991, Figures 2a and 3]). The number and age of the negative $\delta^{18} \mathrm{O}$ excursions in the Orca Basin cores differ slightly depending on the core [see Flower and Kennett, 1990; Keigwin et al., 1991]. The age estimates for the negative $\delta^{18} \mathrm{O}$ excursions in $\mathrm{RC} 12-10$ are within a few hundred years of the events recorded in the Bermuda Rise and Orca Basin cores. However, we do not consider the differences significant because minor changes in the age model for RC 12-10 could easily change the age estimates for the lower part of our record by a few hundred years.

[20] The brief rebound to more positive $\delta^{18} \mathrm{O}$ starting at $10.2 \mathrm{ka}$ in RC 12-10 may be related to the Younger Dryas cooling event that reduced meltwater discharge into the GOM [e.g., Broecker et al., 1989; Flower and Kennett, 1990] and resulted in cooler sea surface temperatures in the northern GOM [Flower and Kennett, 1990, 1995]. However, the rebound to more positive $\delta^{18} \mathrm{O}$ is not well developed in the RC 12-10 and the expected age of the Younger Dryas event is slightly older (11-10 ka). In addition our faunal assemblages and faunal SST estimates do not show clear evidence for cooling associated with the trend to more positive $\delta^{18} \mathrm{O}$ starting at $10.2 \mathrm{ka}$. The $\mathrm{RC} 12-10$ record does not contain a typical Younger Dryas signal.

[21] Variations in the southern margin of the Laurentide Ice Sheet associated with the final melting of the Laurentide Ice Sheet (meltwater pulse 2; Clark et al. [2001]) resulted in a complex switching of meltwater discharge between the North Atlantic and the GOM [Licciardi et al., 1999; Clark et al., 2001]. The approximately $1 \%$ variation seen in the $\delta^{18} \mathrm{O}$ record of RC $12-10$ between 9.5 and $7 \mathrm{ka}$ is at least partly due to fluctuations in meltwater discharge into the GOM.

[22] The alternation of meltwater routes during the last stages of the deglaciation likely had significant impact on thermohaline circulation in the North Atlantic [Keigwin et al., 1991]. Routing of meltwaters through the St. Lawrence Seaway injected freshwater to the high-latitude North Atlantic. The influx of meltwater reduced surface water density and inhibited sinking of surface waters and thus reduced thermohaline circulation [Boyle and Keigwin, 1987; Broecker et al., 1989; Licciardi et al., 1999]. Since routing of meltwater through the St. Lawrence Seaway into the North Atlantic would reduce or eliminate the amount of meltwater being transported down the Mississippi River into the GOM, the $\delta^{18} \mathrm{O}$ of surface-dwelling foraminifers in the GOM would become more positive when meltwater was deflected into the North Atlantic. Although RC12-10 in the western GOM is not ideally located to monitor changes in freshwater discharge from the Mississippi River, we note that positive $\delta^{18} \mathrm{O}$ excursions centered at about $9 \mathrm{ka}$ and 7.8 ka coincide closely with the beginning of two intervals identified in continental records when meltwater discharge was switched from the GOM to the northeastern Atlantic (R2, $9.1 \mathrm{ka}$ and R1, $7.7 \mathrm{ka}$; see Clark et al. [2001]).

[23] The RC 12-10 $\delta^{18} \mathrm{O}$ record younger than 7 ka shows considerable high-frequency variability and the $\delta^{18} \mathrm{O}$ show a shift toward more positive values at about $4.0 \mathrm{ka}$. The average $\delta^{18} \mathrm{O}$ between 9.5 and $4 \mathrm{ka}$ is $-1.6 \%$ whereas the average value between $4 \mathrm{ka}$ and the top of the record is $-1.3 \%$. Values centered at about $5.6 \mathrm{ka}$ are as negative as 
the meltwater-related excursions observed during the deglaciation. The very negative $\delta^{18} \mathrm{O}$ centered $\sim 6.0$ ka cannot be caused by influx of glacial meltwater into the GOM because the Laurentide Ice Sheet had completely melted by $7 \mathrm{ka}$ [Licciardi et al., 1999; Clark et al., 2001].

\section{Millennial-Scale Variability: Globigerinoides Sacculifer}

[24] Globigerinoides sacculifer is a surface-dwelling species common in the tropical Atlantic and Caribbean. Foraminifer assemblages in core-top samples from the Caribbean usually have greater than $15 \%$ G. sacculifer [Kipp, 1976]. In the Gulf of Mexico, the distribution of $G$. sacculifer is associated with the Loop Current [Brunner, 1979]. Figure 5 shows abundance of G. sacculifer in coretop assemblages that are younger than 1500 calendar years [Dowsett et al., 2003a, 2003b]. Globigerinoides sacculifer is very abundant in the core-top assemblage from the southeastern GOM where the warm Loop Current and Caribbean surface waters are present all year. The abundance of $G$. sacculifer in the remaining GOM coretop assemblages declines toward the west and north where the Loop Current influence is seasonal. The abundance of G. sacculifer is lowest in areas near the Texas and Louisiana coast where Loop Current influence is minimal all year. We conclude that variations in the abundance of G. sacculifer in assemblages from RC 12-10 are related to changes in penetration of the Loop Current into the GOM. Higher abundances of $G$. sacculifer in RC 12-10 assemblages indicate increased transport of Caribbean surface waters into the western GOM.

[25] Figure 6 compares G. sacculifer abundance variations in RC 12-10 with a proxy for climate derived from a sediment core from Lake Miragoane, Haiti. $\delta^{18} \mathrm{O}$ from ostracodes in Lake Miragoane samples reflect changes in the hydrologic balance, which are manifest as variations in the precipitation/evaporation $(\mathrm{P} / \mathrm{E})$ ratio [Hodell et al., 1991]. More negative $\delta^{18} \mathrm{O}$ indicate a $\mathrm{P} / \mathrm{E}$ increase, which in turn indicates higher lake levels [Hodell et al., 1991]. The Lake Miragoane $\delta^{18} \mathrm{O}$ record shows substantial highfrequency variability but in general a $\delta^{18} \mathrm{O}$ decrease from maximum values at $10.5 \mathrm{ka}$ to a broad minimum in values centered at about $6 \mathrm{ka} . \delta^{18} \mathrm{O}$ then increases in several steps to the present. Two distinct excursions to negative $\delta^{18} \mathrm{O}$ occur at about $9.1 \mathrm{ka}$ and $8.2 \mathrm{ka}$. An interval of very positive $\delta^{18} \mathrm{O}$ centered at about $2 \mathrm{ka}$ is followed upsection by an excursion to more negative $\delta^{18} \mathrm{O}$ centered at about $1 \mathrm{ka}$. Inspection of Figure 6 shows that the general longterm abundance pattern of G. sacculifer in RC 12-10 is similar to the ostracode $\delta^{18} \mathrm{O}$ record from Lake Miragoane. Low abundances of G. sacculifer occur between 7.5 and $10.5 \mathrm{ka}$. The abundance of G. sacculifer increases to an interval of maximum values centered at about $5.5 \mathrm{ka}$ and then decreases toward the present. An interval of minimum abundance values is centered at about $1.8 \mathrm{ka}$. Two distinct excursions to G. sacculifer maxima in the RC 12-10 record at about 9.0 and $8.1 \mathrm{ka}$ match the Lake Miragoane $\delta^{18} \mathrm{O}$ excursions at $9.1 \mathrm{ka}$ and $8.2 \mathrm{ka}$ within the uncertainties in the two independent ${ }^{14} \mathrm{C}$ chronologies.
[26] Hodell et al. [1991] concluded that migration of the average position of the ITCZ during the Holocene explained the long-term variation in the isotope record from Lake Miragoane. The dotted line in Figure 6a shows changes in solar insolation related to changes in Earth's orbit around the Sun. Increased summer insolation from $10.5 \mathrm{ka}$ to about $5 \mathrm{ka}$ at $10^{\circ} \mathrm{N}$ results in warmer Northern Hemisphere conditions. Decreased summer insolation from $5 \mathrm{ka}$ to the present results in cooler Northern Hemisphere conditions. By analogy with changes associated with the seasonal cycle, Hodell et al. [1991] reasoned that warmer Northern Hemisphere temperatures would cause the average position of the ITCZ to move to the north and cooler Northern Hemisphere temperatures would cause the ITCZ to move south. We conclude that orbitally forced changes in the average position of the ITCZ also explain the long-term G. sacculifer abundance variations. From 10.5 ka to about 5 ka warming of the Northern Hemisphere and resulting northward movement in the average position of the ITCZ enhanced easterly winds bringing increased precipitation to Haiti and greater transport of Caribbean surface waters into the GOM. After $\sim 5$ ka decreasing summer insolation in the Northern Hemisphere and resulting southward movement of the average position of the ITCZ began to decrease influence of easterly winds. Thus precipitation in Haiti and transport of surface waters from the Caribbean into the GOM were reduced. Haug et al. [2001] used the same reasoning to explain changes in continental runoff recorded in sediments of the Cariaco Basin, Venezuela. At the beginning of the Holocene, as the ITCZ moved north, increased precipitation along the northern coast of Venezuela resulted in increased runoff into the Cariaco Basin. Precipitation and thus runoff then declined toward the present as the average position of the ITCZ moved closer to the equator and easterly winds were deflected to the south [Haug et al., 2001]. A similar pattern has been observed in proxy records from North Africa [Street and Grove, 1979; Gasse and Van Campo, 1994]. Northward movement of the ITCZ at the beginning of the Holocene resulted in high lake levels in the mid-Holocene that were then followed by more arid conditions and low lake levels toward the present as the ITCZ migrated back toward the equator [e.g., Gasse and Van Campo, 1994, Figures 5 and 6].

[27] Our interpretation implies that maximum penetration of the Loop Current into the GOM and maximum precipitation in the region would occur between 6.5 and 4.5 ka. Basically, the modern summer circulation mode would be enhanced at the expense of the modern winter circulation mode (Figure 1). The G. ruber $\delta^{18} \mathrm{O}$ around $6 \mathrm{ka}$ are similar to values seen during the major influx of glacial meltwater during the last deglaciation (Figure 3). Our preferred interpretation is that the very negative G. ruber $\delta^{18} \mathrm{O}$ indicates more freshwater was incorporated into the surface waters in the western GOM either through increased local precipitation, increased runoff or a combination of both. Alternatively, it is possible that the Loop Current itself has a lower salinity at this time in response to an increase in Caribbean rainfall. We cannot, however, exclude the possibility that higher summer SST was partly responsible for the more negative $G$ ruber $\delta^{18} \mathrm{O}$. 


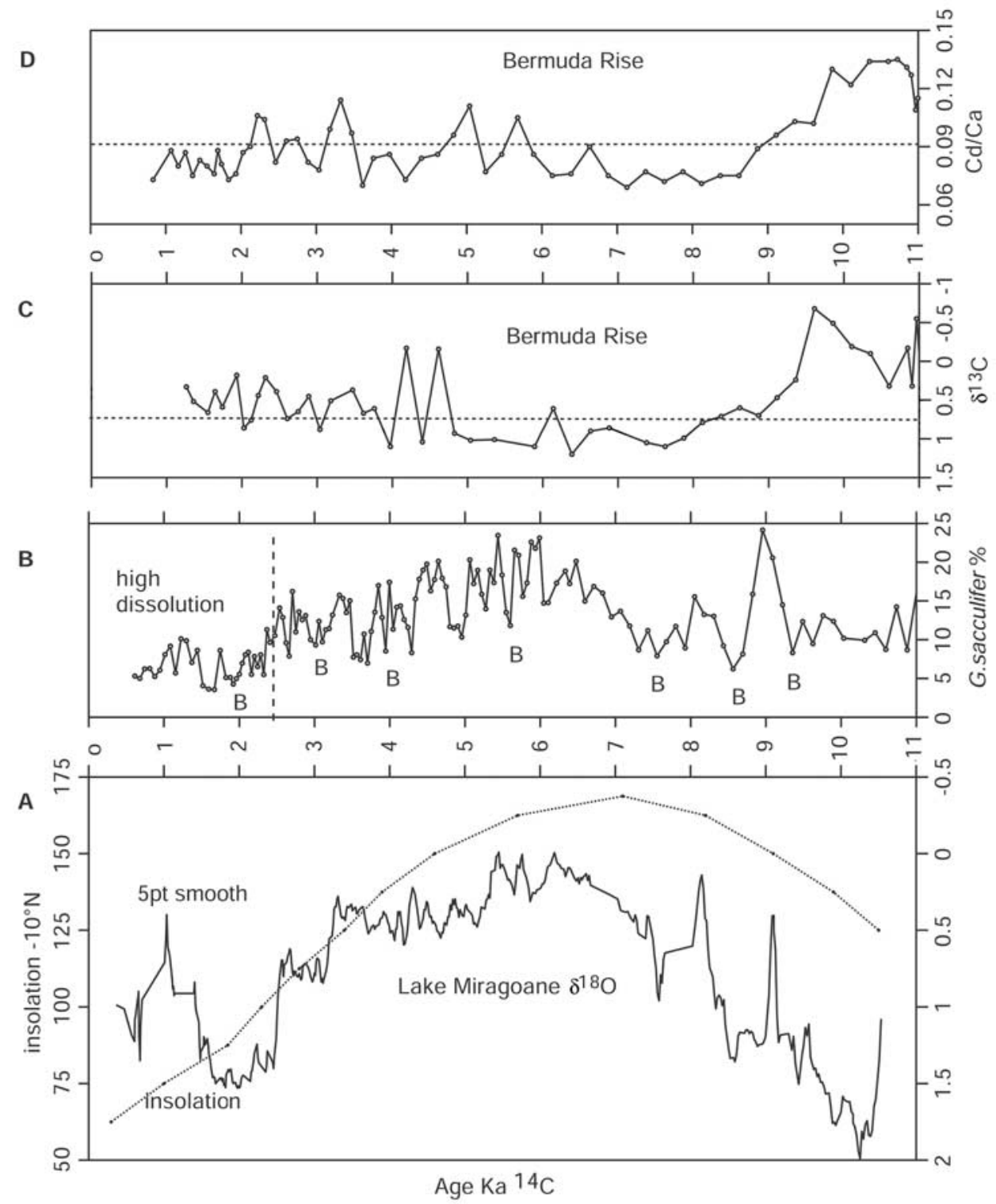

Figure 6. Plot comparing climate proxies from the Gulf of Mexico, Lake Miragoane Haiti, and the Bermuda Rise. (a) $\delta^{18} \mathrm{O}$ from ostracodes in a sediment core from Lake Miragoane, Haiti. Plot is 5 point running average of individual analyses. In this lake more negative isotopic values indicate increased precipitation over evaporation and thus higher lake levels. Chronology in radiocarbon years is derived from 12 AMS ${ }^{14} \mathrm{C}$ dates from the Lake Miragoane core. The dotted line above the isotope data is a measure of solar insolation at $10^{\circ} \mathrm{N}$ latitude [after Hodell et al., 1991]. (b) Relative abundance of G. sacculifer in faunal assemblages from RC 12-10 for last $11 \mathrm{ka}$. The letter B indicate decreases in G. sacculifer abundances that match within 200 years ages of cold events identified in subpolar North Atlantic climate records [Bond et al., 2001] (see text for discussion). Dashed line denotes lower limit of samples showing evidence of dissolution (high fragmentation). (c) Benthic foraminifer carbon isotope record $\left({ }^{13} \mathrm{C}\right)$ from Bermuda Rise Core EN $120 \mathrm{GGC1}$ [after Boyle and Keigwin, 1987]. (d) Benthic foraminifer Cd/Ca ratio record from Bermuda Rise Core EN 120 GGC1 [after Boyle and Keigwin, 1987]. More positive $\delta^{13} \mathrm{C}$ and lower $\mathrm{Cd} / \mathrm{Ca}$ indicate lower nutrient content of bottom waters and thus increased North Atlantic Deep Water.

[28] The faunal data from Gyre 97-6 PC 20 also support the interpretation that the Loop Current had increased influence in the GOM during the mid-Holocene. Globigerinoides sacculifer consistently makes up $15 \%$ of foraminifer assemblages from Gyre 97-6 PC 20 (Figure 4) between 6.5 and $4.5 \mathrm{ka}$ indicating that the Loop Current consistently penetrated well into the northern GOM during that time interval. Overall the various proxies indicate that transport 
of Caribbean waters into the GOM was high between 6.5 and $4.5 \mathrm{ka}$.

[29] Increased transport of Caribbean surface waters into the GOM should also result in increased transport of water vapor into the North Atlantic sector [Oglesby et al., 1989]. A number of studies indicate that effective moisture in the eastern US was higher during the mid-Holocene. For example lake levels in central New York were high between 8.5 and $5.5 \mathrm{ka}$ [Dwyer et al., 1996]. Evidence for increased precipitation in the northeastern and southeastern US between about $8.5 \mathrm{ka}$ and $4.5 \mathrm{ka}$ are provided by pollen records [e.g., Webb et al., 1993] and geomorphic studies [Leigh and Feeney, 1995].

[30] Increased transport of Caribbean surface waters into the GOM implies increased flow of surface waters out through the Florida Straits, which would likely enhance Gulf Streamflow bringing more warm salty water to the subpolar North Atlantic and potentially increasing thermohaline circulation. Support for increased northward transport in the Gulf Stream during the mid-Holocene is provided by detailed alkenone SST estimates from the Norwegian Sea [Calvo et al., 2002] which indicate that the warmest temperatures in the last $10 \mathrm{ka}$ occurred between 8.5 and $5.5 \mathrm{ka}$. Evidence for increased thermohaline circulation at this interval is provided by benthic foraminifer $\delta^{13} \mathrm{C}$ and $\mathrm{Cd} / \mathrm{Ca}$ records from Bermuda Rise core EN 120 GGC1 (Figure 6). EN120 GGC1 was recovered from a depth of $4500 \mathrm{~m}$ and is well located to monitor changes in North Atlantic Deep Water circulation [Boyle and Keigwin, 1987]. The $\delta^{13} \mathrm{C}$ and $\mathrm{Cd} / \mathrm{Ca}$ data are considered to be proxies for nutrient values in bottom water and thus can be used to monitor deep-water source [Boyle and Keigwin, 1987]. More positive $\delta^{13} \mathrm{C}$ values and smaller $\mathrm{Cd} / \mathrm{Ca}$ (depleted nutrient levels) indicate increasing influence of North Atlantic Deep Water. The $\delta^{13} \mathrm{C}$ record shows more positive values between $\sim 8 \mathrm{ka}$ and $4.8 \mathrm{ka}$ which is consistent with increased production of North Atlantic Deep Water and thus increased thermohaline circulation during the interval when $G$. sacculifer is abundant in $\mathrm{RC}$ 12-10 samples. $\mathrm{Cd} / \mathrm{Ca}$ are at a minimum between 8.5 and $6 \mathrm{ka}$ and thus indicate a slightly older interval for increased influence of North Atlantic Deep Water at the EN 120 GGC1 site. Some of the differences between the two proxies in EN 120 GGC1 could be due to uneven sampling of high-frequency variability. Additional work is needed to link the changes seen in GOM surface water conditions with deep-water circulation in the North Atlantic.

[31] We also note that the overall northward migration of the ITCZ during the early to mid-Holocene should result in records from the Southern Hemisphere that are opposite in sign to Northern Hemisphere records. Analyses of sediment cores from Lake Titicaca on the high plateau in the tropical Andes indicate that maximum aridity and lowest water levels occurred between 7.4 and 5 ka [Baker et al., 2001]. In general, water levels at Lake Titicaca have been rising since $5 \mathrm{ka}$. Thus the interval of maximum aridity in Lake Titicaca corresponds approximately with the interval of increased moisture in the Caribbean-GOM region. Similarly, the trend toward more arid conditions over the last few thousand years suggested by the RC 12-10 and Lake
Miragoane records are mirrored by a trend toward increasing moisture supply in the Lake Titicaca record.

\section{Century-Scale Variability}

[32] Inspection of RC 12-10 G. sacculifer abundance data shows well-defined century-scale cycles superimposed on the long-term Holocene trends. The cycles are best developed between about $7 \mathrm{ka}$ and 2. $5 \mathrm{ka}$ (Figure 6). As was noted in a previous section, multiproxy studies of subpolar and subtropical North Atlantic cores have identified quasiperiodic oscillations between cool and warm extremes during the Holocene. The oscillations have a period of about 1500 years and are marked by prominent cool events [Bond et al., 1999]. The ages of the Holocene cool events 1-7 [Bond et al., 2001, Figure 2] are centered at $\sim 1.9,3.2,4.2,5.3,7.8,8.8$, and 9.4 (radiocarbon) ka.

[33] Distinct excursions to lower abundances of $G$. sacculifer in RC 12-10 match within 200 years the ages of Bond events 1-6 (Figure 6). Thus major cooling events detected in the subpolar North Atlantic can be recognized in the GOM record. However, the GOM record includes more cycles than can be explained by a quasiperiodic 1500-year cycle. In fact, more detailed study of subpolar North Atlantic cores has revealed centennial-scale cycles (200 to 500 year) within the framework of the 1500 year cycle [Bond et al., 2001].

[34] We performed spectral analyses on time series of $G$. sacculifer relative abundance from cores RC 12-10 and Gyre 97-6 PC 20 to quantify the high-frequency variability evident in Figures 4 and 6. We applied several techniques, including "traditional" (Blackman-Tukey), maximum entropy and the multitaper method (MTM) [Ghil et al., 2002]. Since most published studies of the frequency variation of Holocene climate records are in calendar years, we used the INTCAL 98 radiocarbon age calibration [Stuiver et al., 1998] to convert our radiocarbon chronology to calendar years BP and did frequency analyses of our data in both radiocarbon-year and calendar-year domains. We analyzed the interval (in calendar years) of $7.4 \mathrm{ka}$ to $2.8 \mathrm{ka}$ because it provides $\sim 50$-year resolution data from both cores and avoids the top of the RC 12-10 record that is affected by dissolution. All methods and both chronologies yield similar results. Figure 7 and the following discussion are based on the MTM analyses in calendar years. The spectra from RC 1210 and Gyre 97-6 PC 20 show a significant broad spectral peak with respect to a red noise background spectra $(95 \%$ confidence level) corresponding to a cycle with a period near 300 years. In addition the spectra of RC 12-10 contains a cycle with period near 550 years and one near 200 years. The Gyre 97-6 PC 20 spectra indicate the presence of cycles with periods near 2,000 years, 250 years, 230 years and 170 years (Figure 7 ).

[35] Our results are in agreement with a number of studies (all in calendar years) indicating the presence of substantial century-scale variability in Holocene climate records from different areas. For example, grain-size variations in sediments from Pine Lake near Calgary, Canada, which reflect changing $\mathrm{P} / \mathrm{E}$ conditions, contain several 300 to 1500 year 


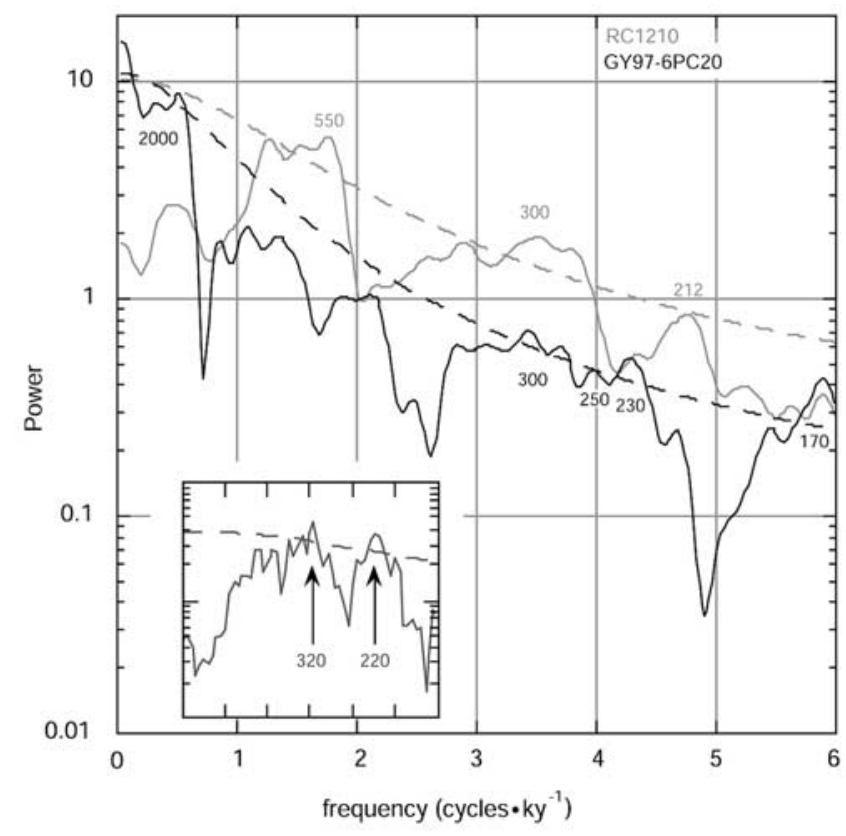

Figure 7. Multitaper method (MTM) spectra (power versus frequency) for Globigerinoidessacculifer relative abundance data from RC 12-10 (red) and Gyre 97-6 PC 20 (black) and ${ }^{14} \mathrm{C}$ production rate (blue inset) time series between 7.4 and $2.8 \mathrm{ka}$ (calendar years). The $95 \%$ significance levels associated with the estimated red noise background is shown by smoothed dashed lines. Arrows on inset refer to significant peaks at approximately 3 and 4.5 cycles/kyr (320 year and 220 year cycles). Several significant signals in the RC 12-10 and Gyre 97-6 PC 20 time series are detected by the method. See text for further discussion. ${ }^{14} \mathrm{C}$ production rate time series is the Stuiver et al. [1991] record with corrections for reservoir effects from Bond et al. [2001]. See color version of this figure at back of this issue.

cycles [Campbell et al., 1998]. Analyses of variance in the abundance of $G$. bulloides, a proxy for upwelling intensity, in Holocene sediments from the Cariaco Basin [Peterson et al., 1991], shows cycles with periods of 381 and 200 years. We analyzed the high-resolution $\mathrm{Ti}$ abundance data, a proxy for runoff, from the Cariaco Basin [Haug et al., 2001] between 7.4 and $2.8 \mathrm{ka}$ and found significant cycles with periods of 138 and 116 years. The subpolar North Atlantic climate records of Bond et al. [2001, supplementary data, Figure 2] show prominent spectral peaks corresponding to cycles with periods around 500, 300 and 200 years (multitaper method). An 200 year cycle has also been documented in lake records of the last $2000+$ years from the Yucatan Peninsula [Hodell et al., 2001]. Thus a number of different records demonstrate that century-scale variability is a pervasive feature of Holocene climate variability.

[36] The $\sim 200$ year cycle that is present in many records is of interest because it coincides with the well known 208 year cycle in ${ }^{14} \mathrm{C}$ production and ${ }^{10} \mathrm{Be}$ flux [e.g., Stuiver et al., 1991; Damon and Sonett, 1991]. Since ${ }^{14} \mathrm{C}$ production rates and ${ }^{10} \mathrm{Be}$ flux are considered to be proxies for solar variability [e.g., Stuiver et al., 1991] the presence of the 200 year cycle in climate proxy records is interpreted as evidence for a strong link between variations in solar output and climate variability [Bond et al., 2001; Hodell et al., 2001; Peterson et al., 1991]. Variance in solar output as monitored by ${ }^{14} \mathrm{C}$ production proxy records is complicated and depending on the technique used several century-scale cycles are present in solar proxy records. For example Stuiver et al. [1991] used the maximum entropy method to document cycles of 414, 216, 142, and 85 years in the record of ${ }^{14} \mathrm{C}$ production. The $\sim 170$ year cycle evident in the Gyre 97-6 PC 20 record and the 138 year cycle in the Cariaco Basin $\mathrm{Ti}$ record are near the $\sim 140$ year cycle reported from solar proxy records [Stuiver and Braziunas, 1989; Stuiver et al., 1991].

[37] The $\sim 300$ year cycle that is significant in our GOM records is not widely reported. However, a $\sim 300$ cycle is prominent, albeit not statistically significant (G. Bond, personal communication, 2002), in the subpolar North Atlantic records of Bond et al. [2001]. We analyzed the ${ }^{14} \mathrm{C}$ production rate record from Bond et al. [2001], which is the Stuiver et al. [1991] record with corrections for reservoir effects, over the 7.4 to $2.8 \mathrm{ka}$ interval and found significant variance at cycles of $\sim 320$ and 220 years (Figure 7 , inset). The $\sim 320$ cycle is similar to the $\sim 300$ cycle found in our GOM records and the subpolar North Atlantic records [Bond et al., 2001].

[38] We conclude that at least some of the high-frequency variation (century scale) in G. sacculifer abundance in our GOM records is forced by solar variability. Movement in the average position of the ITCZ is the mechanism linking changes in solar output with the century-scale variability. We conclude that the average position of the ITCZ varies in response to solar variability on centennial timescales just as the average position of the ITCZ varies in response to orbitally driven insolation changes over the course of the Holocene [Hodell et al., 1991; Haug et al., 2001; this study]. Increased solar output would result in a more northerly position of the ITCZ and thus increased transport of Caribbean surface waters into the GOM and higher percentages of G. sacculifer in RC 12-10 and Gyre 97-6 PC 20 assemblages. Reduced solar output would result in the opposite effect.

\section{Summary and Conclusions}

[39] Foraminifer and isotope data from core RC 12-10 in the western GOM provide a detailed (50-100 year resolution) record of climate variability for the last 14,000 years. Long-term (millennial-scale) trends and changes in the record are related to the previously documented transition from glacial to interglacial conditions and movement of the ITCZ related to orbital forcing. Increased transport of Caribbean surface waters and moisture into the GOM region associated with a northward migration of the average position of the ITCZ occurred in the mid-Holocene between 6.5 and $4.5 \mathrm{ka}$. Faunal-based SST estimates indicate that winter SSTs were slightly warmer than modern during the mid-Holocene. Our data provide evidence for a mid-Holocene interglacial maximum, or hypsithermal 
in the GOM that is consistent with records of a midHolocene hypsithermal interval in the region [e.g., Haug et al., 2001].

[40] $\delta^{18} \mathrm{O}$ of the surface dwelling planktic foraminifer G. ruber show excursions to very negative values between $14 \mathrm{ka}$ and $10.5 \mathrm{ka}$ that reflect influx of meltwater into the GOM during the melting of the Laurentide Ice Sheet. Excursions to more positive $\delta^{18} \mathrm{O}$ centered at $\sim 9 \mathrm{ka}$ and $7.8 \mathrm{ka}$ coincide closely with the beginning of two intervals identified in continental records as times when meltwater discharge was switched from the GOM to the northeastern Atlantic (R2, $9.1 \mathrm{ka}$ and R1 $7.7 \mathrm{ka}$ of Clark et al. [2001]).

[41] Abundance variations of G. saccuilfer show submillennial-scale variability throughout most of the Holocene. A significant cycle near 300 years is present in both our data and the record of ${ }^{14} \mathrm{C}$ production. Thus forcing for the $\sim 300$ year cycle in the GOM records may be related to solar variability. A $\sim 200$ year cycle in RC 12-10 and a number of other climate records is characteristic of solar variability as monitored in ${ }^{14} \mathrm{C}$ production and ${ }^{10} \mathrm{Be}$ flux. Similarly the $\sim 170$ year cycle found in the Gyre 97-6 PC 20 record is close to the 140 year cycle that occurs in solar variability proxy records. The records of variability in $\mathrm{RC}$ 12-10 and Gyre 97-6 PC 20 are consistent with results from the Cariaco Basin, the Yucatan Peninsula and the subpolar North Atlantic indicating that century-scale variability is pervasive in detailed climate proxy records of the Holocene. In addition the similarity in cycles found in many proxy climate records and proxy records for solar variability indicates that some of the high-frequency (century-scale) climate variability of the current interglacial is due to external (solar) forcing.

[42] Acknowledgments. We thank Dave Hodell for data from Lake Miragoane, Lloyd Keigwin for data from EN 120, G. Haug and L. Peterson for data from the Cariaco Basin, and $\mathrm{G}$. Bond for the modified ${ }^{14} \mathrm{C}$ production record. We thank Dave Twichell for providing access to Gyre 97-6 PC 20. We thank Ellen Roosen for assistance sampling Gyre 97-6 PC 20 and R. Lotti for assistance in sampling RC 12-10. Bethany Boisvert, Kate Pavich and Christie Stephans provided technical assistance throughout the study. We thank Milan Pavich and Lloyd Keigwin for discussions. Ben Flower, Lloyd Keigwin, Lisa Osterman and an anonymous reviewer provided constructive comments that improved the manuscript. This work was partially supported by NSF, Division of Ocean Sciences.

\section{References}

Alley, R. B., P. A. Mayewski, T. Sowers, M. Stuiver, K. C. Taylor, and P. U. Clark, Holocene climatic instability: A prominent, widespread event 8200 yr ago, Geology, 25, 483-486, 1997.

Baker, P. A., G. O. Seltzer, S. C. Fritz, R. B. Dunbar, M. J. Grove, P. M. Tapia, S. L. Cross, H. D. Rowe, and J. P. Broda, The history of South American tropical precipitation for the past 25,000 years, Science, 291, 640-643, 2001.

Benson, L., M. Kashgarian, R. Rye, S. Lund, F. Paillet, J. Smoot, C. Kester, S. Mensing, D. Meko, and S. Lindström, Holocene multidecadal and multicentennial droughts affecting northern California and Nevada, Quat. Sci. Rev., 21, 659-682, 2002.

Boltovskoy, E., and V. I. Toutah, Preservation index and preservation potential of some foraminiferal species, J. Foraminiferal Res., 22, 267-273, 1992.

Bond, G., W. Showers, M. Cheseby, R. Lotti, P. Almasi, P. deMenocal, P. Priore, H. Cullen, I. Hajdas, and G. Bonani, A pervasive millennial-scale cycle in North Atlantic Holocene and glacial climates, Science, 278, 1257-1266, 1997.

Bond, G., W. Showers, M. Elliot, M. Evans, R. Lotti, I. Hajdas, G. Bonani, and S. Johnson, The North Atlantic's 1-2 kyr climate rhythm: Relation to Heinrich events, Dansgaard/Oeschger cycles and the Little Ice Age, in Mechanisms of Global Climate Change at Millennial Time Scales, Geophys. Monogr. Ser., vol. 112, edited by P. Clark, R. Webb, and L. D. Keigwin, pp. 35-58, AGU, Washington, D. C., 1999.

Bond, G., B. Kromer, J. Beer, R. Muscheler, M. N. Evans, W. Showers, S. Hoffmann, R. Lotti-Bond, I. Hajdas, and G. Bonani, Persistant solar influence on North Atlantic climate during the Holocene, Science, 294, 2130-2136, 2001

Boyle, E. A., and L. Keigwin, North Atlantic thermohaline circulation during the past 20,000 years linked to high-latitude surface temperature, Nature, 330, 35-40, 1987.
Broecker, W. S., J. P. Kennett, B. P. Flower, J. T. Teller, S. Trumbore, G. Bonani, and W. Wolfli, Routing of meltwater from the Laurentide ice sheet during the Younger Dryas cold episode, Nature, 341, 318-321, 1989.

Brown, P., J. P. Kennett, and B. L. Ingram, Marine evidence for episodic Holocene megafloods in North America and the northern Gulf of Mexico, Paleoceanography, 14, 498-510, 1999.

Brunner, C. A., Distribution of planktonic foraminifera in surface sediments of the Gulf of Mexico, Micropaleontology, 25, 325-335, 1979.

Brunner, C. A., Paleoceanography of surface waters in the Gulf of Mexico during the Late Quaternary, Quat. Res., 17, 105-119, 1982.

Calvo, E., J. Grimalt, and E. Jansen, High resolution $U_{37}^{k}$ sea surface temperature reconstruction in the Norwegian Sea during the Holocene, Quat. Sci. Rev., 21, 1385-1394, 2002.

Campbell, I. D., C. Campbell, M. J. Apps, N. W. Rutter, and A. G. G. Bush, Late Holocene $\sim 1500$ yr climatic periodicities and their implications, Geology, 26, 471-473, 1998.

Cane, M., and A. C. Clement, A role for the tropical Pacific coupled ocean-atmosphere system on Milankovitch and millennial timescales, part II: Global impacts, in Mechanisms of Global Climate Change at Millennial Time Scales, Geophys. Monogr. Ser, vol. 112, edited by P. Clark, R. Webb, and L. D. Keigwin, pp. 373-383, AGU, Washington, D. C., 1999.

Clark, P. U., S. J. Marshall, G. K. C. Clarke, S. W. Hostetler, J. M. Licciardi, and J. T. Teller, Freshwater forcing of abrupt climate change during the last glaciation, Science, 293, 283-287, 2001.

Damon, P. E., and C. P. Sonett, Solar and terrestrial components of the atmospheric ${ }^{14} \mathrm{C}$ variation spectrum, in The Sun in Time, edited by C. P. Sonett, M. S. Giampapa, and M. S. Matthews, pp. 360-388, Univ. of Ariz. Press, Tucson, Ariz., 1991.
DeMenocal, P., J. Ortiz, T. Guilderson, and M. Sarnthein, Coherent high-and low-latitude variability during the Holocene warm period, Science, 288, 2198-2202, 2000.

Denton, G. H., and W. Karlén, Holocene climatic variations-Their pattern and possible cause, Quat. Res., 3, 155-205, 1973.

Dowsett, H. J., C. A. Brunner, S. Verardo, and R. Z. Poore, Gulf of Mexico planktic foraminifer core-top calibration set: Raw data, U.S Geol. Surv. Open File Rep. 03-08, 15 pp., Reston, Va., 2003a.

Dowsett, H. J., S. Verardo, and R. Z. Poore, Gulf of Mexico planktic foraminifer transfer function GOM2: Preliminary report, U.S. Geol. Surv. Open File Rep. 03-61, 48 pp., Reston, Va., 2003b.

Dwyer, T. R., H. T. Mullins, and S. C. Good, Paleaoclimatic implications of Holocene lakelevel fluctuations, Owasco Lake, New York, Geology, 24, 519-522, 1996.

Ericson, D. B., and G. Wollin, Pleistocene climates and chronology in deep-sea sediments, Science, 162, 1227-1234, 1968.

Flower, B. P., and J. P. Kennett, The Younger Dryas cool episode in the Gulf of Mexico, Paleoceanography, 5, 949-961, 1990.

Flower, B. P., and J. P. Kennett, Biotic responses to temperature and salinity changes during the last deglaciation, Gulf of Mexico, in Effects of Past Global Changes on Life, pp. 209-220, Natl. Acad., Washington, D. C., 1995.

Flower, B. P., D. W. Hastings, H. W. Hill, D. J. Hollander, J. LoDico, and T. M. Quinn, Deglacial warming in the Gulf of Mexico preceded Laurentide Ice Sheet meltwater input: Implications for early tropical/subtropical climate forcing, Eos Trans. $A G U, 83(47)$, Fall Meet. Suppl., Abstract PP71A-0372, 2002.

Gasse, F., and E. Van Campo, Abrupt post-glacial climate events in west Asia and north Africa monsoon domains, Earth Planet. Sci. Lett., 126, 435-456, 1994.

Haug, G. H., K. A. Hughen, D. M. Sigman, L. C. Peterson, and U. Röhl, Southward migration of the Intertropical Convergence Zone through 
the Holocene, Science, 293, 1304-1308, 2001.

Hodell, D. A., J. H. Curtis, G. A. Jones, A. Higuera-Gundy, M. Brenner, M. W. Binford, and K. T. Dorsey, Reconstruction of Caribbean climate change over the past 10,500 years, Nature, 352, 790-793, 1991.

Hodell, D. A., B. Mark, J. H. Curtis, and T. Guilderson, Solar forcing of drought frequency in the Maya Lowlands, Science, 292, $1-4,2001$.

Imbrie, J., and N. G. Kipp, A new micropaleontological method for quantitative paleoclimatology: Application to a Late Pleistocene Caribbean core, in Late Cenozoic Glacial Ages, edited by K. K. Turekian, pp. 71-181, Yale Univ. Press, New York, 1971.

Keigwin, L. D., The Little Ice Age and Medieval Warm Period in the Sargasso Sea, Science, 274, 1504-1508, 1996.

Keigwin, L. D., and G. A. Jones, Glacial-Holocene stratigraphy, chronology, and paleoceanographic observations on some North Atlantic sediment drifts, Deep Sea Res., 36, 845-867, 1989.

Keigwin, L. D., G. A. Jones, S. J. Lehman, and E. A. Boyle, Deglacial meltwater discharge, North Atlantic deep circulation, and abrupt climate change, J. Geophys. Res., 96, 16,81116,826, 1991.

Kennett, J. P., and P. Huddlestun, Late Pleistocene paleoclimatology, foraminiferal biostratigraphy and tephrochronology, western Gulf of Mexico, Quat. Res., 2, 38-69, 1972.

Kennett, J. P., and N. J. Shackleton, Laurentide ice sheet meltwater recorded in Gulf of Mexico deep-sea cores, Science, 188, 147-150, 1975.

Kennett, J. P., K. Elmstrom, and N. Penrose, The last deglaciation in Orca Basin, Gulf of Mexico: High-resolution planktonic foraminiferal changes, Palaeogeogr. Palaeoclimatol. Palaeoecol., 50, 189-216, 1985.

Kipp, N. G., New transfer function for estimating past sea-surface conditions from sea-bed distribution of planktonic foraminiferal assemblages in the North Atlantic, in Investigations of Late Quaternary Paleoceanography and Paleoclimatology, edited by R. M. Cline and J. D. Hays, pp. 3-41, Geol. Soc. of Am., Boulder, Colo., 1976.

Leigh, D. S., and T. P. Feeney, Paleochannels indicating wet climate and lack of response to lower sea level, southeast Georgia, Geology, 23, 687-690, 1995.

Leventer, A., D. F. Williams, and J. P. Kennett, Dynamics of the Laurentide ice sheet during the last deglaciation: Evidence from the Gulf of Mexico, Earth Planet. Sci. Lett., 59, 11-17, 1982.

Licciardi, J. M., J. T. Teller, and P. U. Clark, Freshwater routing by the Laurentide ice sheet during the last deglaciation, in Mechanisms of Global Climate Change at Millennial Time Scales, Geophys. Monogr. Ser., vol. 112, edited by P. Clark, R. Webb, and L. D. Keigwin, pp. 177-201, AGU, Washington, D. C., 1999.

Malmgren, B., and J. P. Kennett, Principal component analysis of Quaternary planktic foraminifera in the Gulf of Mexico: Paleoclimatic applications, Mar. Micropaleontol., 1, 299306, 1976.

Mayle, F. E., R. Burbridge, and T. J. Killeen, Millennial-scale dynamics of southern Amazonian rain forests, Science, 290, 2291-2294, 2000.

Metcalfe, S. E., S. L. O'Hara, M. Caballero, and S. J. Davies, Records of Late Pleistocene-Holocene climatic change in Mexico-A review, Quat. Sci. Rev, 19, 699-721, 2000.

Müller-Karger, F. E., J. J. Walsh, R. H. Evans, and M. B. Meyers, On the seasonal phytoplankton concentration and sea surface temperature cycles of the Gulf of Mexico as determined by satellites, J. Geophys. Res., $96,12,645-12,665,1991$.

Oglesby, R. J., K. A. Maasch, and B. Saltzman, Glacial meltwater cooling of the Gulf of Mexico: GCM implications for Holocene and present-day climates, Clim. Dyn., 3, 115-133, 1989.

Parker, F. L., Planktonic foraminiferal species in Pacific sediments, Micropaleontology, 8, 219254, 1962.

Peixóto, J. P., and A. H. Oort, The atmospheric branch of the hydrological cycle and climate, in Variations in the Global Water Budget, edited by A. Street-Perrott, M. Beran, and R. Ratcliffe, pp. 5-65, D. Reidel, Norwell, Mass., 1983.

Petersen, K. L., A warm and wet little climatic optimum and a cold and dry little ice age in the southern Rocky Mountains, U.S.A., Clim. Change, 26, 243-269, 1994.

Peterson, L. C., J. T. Overpeck, N. G. Kipp, and J. Imbrie, A high-resolution Late Quaternary upwelling record from the anoxic Cariaco Basin, Venezuela, Paleoceanography, 6, 99-119, 1991

Poore, R. Z., Oligocene through Quaternary planktic foraminiferal biostratigraphy of the North Atlantic: DSDP Leg 49, Initial Rep. Deep Sea Drill. Proj., 49, 447-517, 1979.

Sheinbaum, J., J. Candela, A. Badan, and J. Ochoa, Flow structure and transport in the Yucatan Channel, Geophys. Res. Lett., 29(3), 1040, doi:10.1029/2001GL013990, 2002.

Street, F. A., and A. T. Grove, Global maps of lake-level fluctuations since 30,000 yr B.P., Quat. Res., 12, 83-118, 1979.

Stuiver, M., and T. F. Braziunas, Atmospheric ${ }^{14} \mathrm{C}$ and century-scale solar oscillations, Nature, 338, 405-408, 1989.

Stuiver, M., T. F. Braziunas, B. Becker, and B. Kromer, Climatic, solar, oceanic, and geomagnetic influences on late-glacial and Holocene atmospheric ${ }^{14} \mathrm{C} /{ }^{12} \mathrm{C}$ change, Quat. Res. $35,1-24,1991$.

Stuiver, M., P. Reimer, E. Bard, W. Beck, G. Burr, K. Hughen, B. Kromer, G. McCormac, J. van der Plicht, and M. Spurk, INTCAL98 radiocarbon age calibration, 24,0000 cal BP, Radiocarbon, 40, 1041-1084, 1998.

Tang, M., and E. R. Reiter, Plateau monsoons of the Northern Hemisphere: A comparison between North America and Tibet, Mon. Weather Rev., 112, 617-637, 1984.

Webb, R. S., K. H. Anderson, and T. Webb III, Pollen response-surface estimates of Late Quaternary changes in the moisture balance of the northeastern United States, Quat. Res., 40, 213-227, 1993.

Woodhouse, C. A., and J. T. Overpeck, Overpeck, 2000 years of drought variability in the central United States, Bull. Am. Meteorol. Soc., 79, 2693-2714, 1998

H. J. Dowsett, R. Z. Poore, and S. Verardo, MS 919, U.S. Geological Survey, 12201 Sunrise Valley Drive, Reston, VA 20192, USA. (hdowsett@usgs.gov; rpoore@usgs.gov; sverardo@usgs.gov)

T. M. Quinn, College of Marine Science, 140 Seventh Ave South, University of South Florida, St. Petersburg, FL 33701, USA. (quinn@seas. marine.usf.edu) 

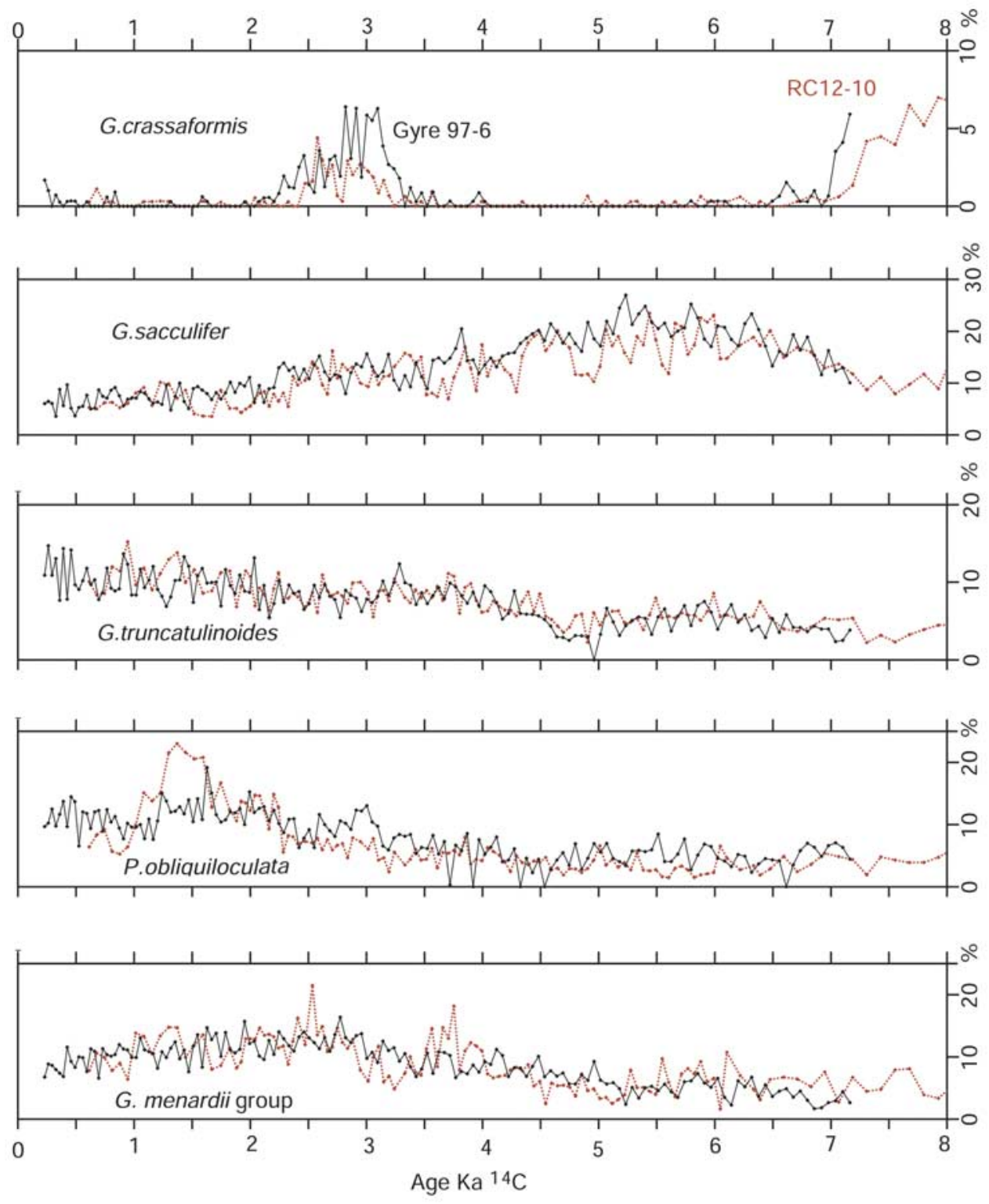

Figure 4. Comparison of relative abundance variations of selected planktic foraminifers in RC 12-10 and Gyre 97-6, PC 20. Chronology is based on independent AMS ${ }^{14} \mathrm{C}$-controlled age models for each core (Figure 2). 


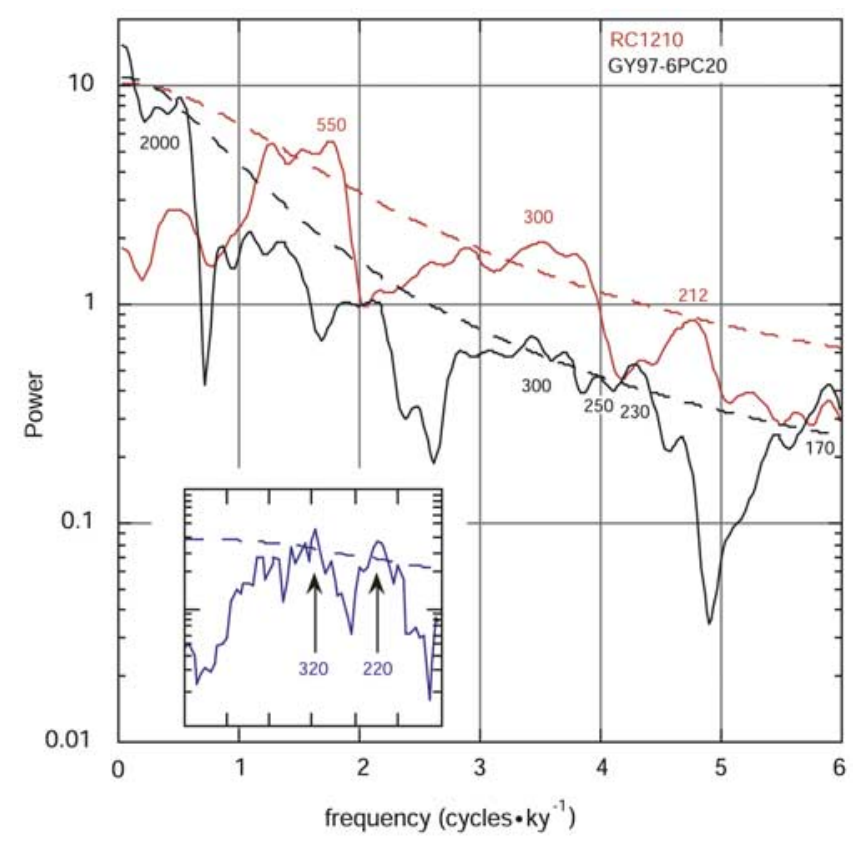

Figure 7. Multitaper method (MTM) spectra (power versus frequency) for Globigerinoidessacculifer relative abundance data from RC 12-10 (red) and Gyre 97-6 PC 20 (black) and ${ }^{14} \mathrm{C}$ production rate (blue inset) time series between 7.4 and $2.8 \mathrm{ka}$ (calendar years). The 95\% significance levels associated with the estimated red noise background is shown by smoothed dashed lines. Arrows on inset refer to significant peaks at approximately 3 and 4.5 cycles/kyr (320 year and 220 year cycles). Several significant signals in the RC 12-10 and Gyre 97-6 PC 20 time series are detected by the method. See text for further discussion. ${ }^{14} \mathrm{C}$ production rate time series is the Stuiver et al. [1991] record with corrections for reservoir effects from Bond et al. [2001]. 